\title{
Influence of continental fraction in recent biogenic carbonate sedimentation in the oriental shelf of Northeastern Brazil
}

\author{
Wanessa Sousa Marques ${ }^{1}$, Eldemar de Albuquerque Menor ${ }^{1}$, Alcides Nobrega Sial ${ }^{1}$, Valderez Pinto \\ Ferreira $^{1}$, George Satander Sá Freire ${ }^{2}$ \& Valdir do Amaral Vaz Manso ${ }^{1}$
}

\begin{abstract}
The influence of continental sediments on formation of recent marine sediments, has been mineralogically and geochemically studied using shelf-floor whole sediments (WS). The studied area corresponds to the oriental shelf of Northeastern Brazil between the 10 to $80 \mathrm{~m}$ isobaths, adjacent to a continental area dominated by semi-arid to humid tropical climate. 47 representative samples from the dominating facies in this shelf have been analyzed by X-ray diffraction (XRD) and chemical analisis and results allowed identification of two types of floor sediments of: (a) quartz-terrigenous dominance and (b) carbonate dominance, whose fraction present distinct mineralogical and geochemical characteristics. In the terrigenous facies, that occur from 10 to $25-55 \mathrm{~m}$ depths, quartz, potassic feldspar and high $\mathrm{Mg}$-calcite predominate, with $\mathrm{Sr}$ generally $<2,200$ $\mathrm{ppm}$. In the carbonate facies, high $\mathrm{Mg}$-calcite and aragonite coexist and predominate, with $\mathrm{Sr}$ concentrations up to $6,400 \mathrm{ppm}$ and ranging $>2,600 \mathrm{ppm}$. In both cases, low-Mg calcite is absent. Even when the terrigenous fraction is found in accessory amounts $(<3 \% \mathrm{WS})$, geochemical signatures, marked by strong intercorrelations $\mathrm{SiO} 2$ - Al2O3 - K2O - Rb, exhibit correlation coefficients with $\mathrm{r} \geq 0.9$, reflecting a continental felsic source. The statistical analyses (co-variation between $\mathrm{Mg} / \mathrm{Ca}$ and $\mathrm{SiO} 2$ ), chemistry and mineralogy of the sediments indicate that textural and mineralogical nature of the substratum is the main factor controlling the biota (dominantly benthonic in this shelf) and that, in these conditions, quartzous terrigenous facies favor species that are preserved in high Mg-calcite instead of those preserved in aragonite. This tendency showed to be independent of depth of sampling between 10 and $55 \mathrm{~m}$.
\end{abstract}

Keywords: biogenic carbonates, Mg-calcite, Northeastern Brazil, terrigenous sediments

\begin{abstract}
Resumo Influência de frações continentais na sedimentação de carbonatos biogênicos recentes na porção oriental da plataforma continental nordeste brasileira. A A influência do aporte continental na formação de carbonatos biogênicos recentes é estudada a partir de dados mineralógicos e geoquímicos nos sedimentos totais do assoalho plataformal. A área estudada corresponde à plataforma do Nordeste Oriental do Brasil, entre as isóbatas de 10 e $80 \mathrm{~m}$, adjacente a uma porção continental dominada por clima tropical semiárido a úmido. Foram selecionadas 47 amostras contendo, em sua maioria, sedimentos carbonáticos, que são dominantes nessa plataforma, para análises XRD e análises químicas. Os resultados definiram dois tipos de fácies, ou sedimentos de composição diferente: os de dominância terrígeno-quartzosa e os de dominância francamente carbonática. Nos sedimentos terrígenos, que ocorrem desde isóbatas de $10 \mathrm{~m}$, até isóbatas entre 25 e $55 \mathrm{~m}$, predominam quartzo, feldspato potássico e calcita de alto magnésio, com teores em $\mathrm{Sr}$ geralmente $<$ $2.200 \mathrm{ppm}$. Nos sedimentos carbonáticos, predominam e coexistem calcita de alto magnesio e aragonita, com teores em Sr geralmente $>2.600$ ppm, chegando a mais de 6.400 ppm. Em ambos os casos, não foi identificável a presença de calcita com alto magnésio. Mesmo quando a fração terrígena é acessória $(<3 \%)$, a assinatura geoquímica, marcada por fortes intercorrelações $\mathrm{SiO} 2-\mathrm{A} 12 \mathrm{O} 3-\mathrm{K} 2 \mathrm{O}-\mathrm{Rb}$ mantém fatores de correlação (r) $\geq$ 0.9 , refletindo a fonte félsica, de orígem continental desses sedimentos terrígenos. As análises estatística (correlação $\mathrm{Mg} / \mathrm{Ca}$ - $\mathrm{SiO} 2$ ), química e mineralogia dos sedimentos indicam que a natureza mineralógica do substrato é fator preponderante de controle da biota (dominantemente bentônica nessa plataforma) e que, nessas condições, as fácies mais terrígeno-quartzosas favorecem espécies preserváveis em calcita com alto magnésio em detrimento de espécies preserváveis em aragonita. Essa tendência mostrou-se independente da isóbata da amostragem desde os 10 até os $55 \mathrm{~m}$.
\end{abstract}

Palavras-chave: carbonatos biogênicos, calcitas magnesianas, fluorescência de raiosX, sedimentos terrígenos.

INTRODUCTION Biogenic carbonates occur habitually in shallow marine water of tropical regions. Due to the metabolism of the species that compose them, biogenic carbonates are chemically heterogeneous, presenting a variety of chemical elements tied to their crystalline structure (Brownlow 1996). Many factors influ-

1 - NEG-LABISE, Department of Geology, Federal University of Pernambuco, Recife (PE), Brazil. E-mail: wsmarq@yahoo.com.br, sial@ufpe.br,menor@terra.com.br, valderez@ufpe.br, vazmanso@uol.com.br

2 - DEGEO, Department of Geology, Federal University of Ceará, Fortaleza (CE), Brazil. E-mail: freire@ufc.br 
ence their mineralogy and spatial distribution, being the type of biota one of them. For example, the major part of the foraminifers precipitate Mg-calcite in their tests, while marine algae of the generus Halimeda precipitate exclusively aragonite (Bilal and Boersma 1998).

Environmental factors as temperature, $\mathrm{pH}, \mathrm{CO}_{2}$ partial pressure, light penetration and availability of oxygen are also determining factors for the distribution of these sediments in the continental shelves. Morse and Mackenzie (1990) pointed to a relationship between shape and complexity of the carbonatic skeleton of different organisms and water temperature, emphasizing that aragonite-producer organisms are, many times, confined to warmer waters. These authors indicated a relationship between growth rate (or calcification) of skeletons and magnesium content in the carbonate structure.

Brownlow (1996) emphasized that organisms could precipitate calcite in either undersaturated or oversaturated in calcium carbonate waters, and that nucleation rate and crystal growth, as well as their dissolution, are delayed by the presence of $\mathrm{Mg}^{++}$in seawater. He also stated that carbonates precipitated in shallowmarine waters are formed mainly by high $\mathrm{Mg}$-calcite (11 to $19 \% \mathrm{Mg}$ ) while low $\mathrm{Mg}$-calcite $(\mathrm{Mg}<11 \%)$ and aragonite are usually subordinate in these facies.

$\mathrm{X}$-ray diffraction analysis (XRD) is a satisfactory method of analysis for telling how much magnesium is in the structure of carbonates (Goldsmith et al. 1961) once its presence decreases the distance between the atomic planes in the crystalline structure of calcite.

Aragonite exhibits distinct behavior with respect to magnesium, because the growth of this carbonate mineral is not affected by presence of this element, since its orthorhombic structure does not admit magnesium in amount large enough to form solid solution, as it happens in calcite. On the contrary, its atomic structure favors the admission of atoms with ionic radius larger than that of calcium (e.g. strontium). In aragonite, calcium is replaced by strontium, lead and, less often, by zinc (Dana 1959).

The scope of this study is to focus on the influence of the continent derived facies in the mineralogy and geochemistry of the carbonatic sedimentation in the continental shelf of the oriental Northeastern Brazil, recognized as one of the richest shelves in biogenic carbonates in the Brazilian coast.

STUDY AREA The continental shelf of oriental Northeastern Brazil, particularly in the state of Ceará (Fig. 1), receives reworked sediments from the Barreiras Formation and from the crystalline basement, by means of rivers of little to intermediate importance (Freire 1985). Rocks of the crystalline basement are predominantly felsic and according to Freire (1985) this basement is covered by Neogene sediments of the Barreiras Formation along the coast. Sediments of the Barreiras Formation are constituted by red clayey sands and conglomerates. Sedimentary limestones also crop out in relatively extensive areas (e.g. Potiguar Basin) in the state of Rio Grande do Norte.
Almost all rivers that transport sediments to the continental shelf have hydrographic basins localized in the semi-arid climate domain (Meireles and Silva 2002).

According to Summerhayes et al. (1975) and Coutinho (1992), this continental shelf (Fig. 1) is relatively narrow $(60-80 \mathrm{~km})$, has a gentle slope (about de $1 \mathrm{~m} / \mathrm{km}$, in average), warm water $\left(25-30^{\circ} \mathrm{C}\right)$, and high salinity (30-38\%o). In general, its intermediate and external domains are entirely covered by biogenic carbonatic sediments, characterized by predominating algalic rests and mollusks, small amount of corals, and total absence of ooids or other forms of carbonatic inorganic precipitation. The depth of shelf break, or the beginning of the continental slope, is between 60 and $70 \mathrm{~m}$ isobaths. These characteristics extend along the continental shelf of other states in Northeastern Brazil, like Pernambuco, studied by Montalverne (1982).

Among the studied samples from greater depths $(>80 \mathrm{~m})$ carbonate nodules have been observed in dark buff color, identified by Amaral (unpublished data) as being Eocene-Oligocene phosphatic limestones of the continental margin, formed by diagenetic phosphatization of carbonate rocks, due to upwelling currents.

METHODS The sampling was carried out by oceanographic dredging and 47 samples have been selected between isobaths from 10 through $80 \mathrm{~m}$, from the continental shelf of Ceará, Piauí, Rio Grande do Norte, Pernambuco, Paraíba and Alagoas states. This sampling includes essentially superficial Holocene sediments, composed of biogenic carbonates and subordinate terrigenous sediments. It was done during the operations of the GEOMAR XVIII (November, 1981) and GEOMAR XXI (November, 1983), on board of the Almirante Câmara oceanographic ship of the Brazilian Navy.

Each sample of whole sediment (WS) was washed and dried out in room temperature, put in plastic recipients and stored in the Marine Geology Laboratory (LGMA), Federal University of Ceará. The preliminary laboratory procedure consisted in homogenizing and quartering and two grams was ground down to 100 meshes in porcelain crucible and were analyzed by X-ray fluorescence, at the Stable Isotope Laboratory (LABISE), Department of Geology and by X-ray diffraction analysis, Physics Department of the Federal University of Pernambuco.

X-ray Fluorescence Analyses Powdered samples (WS), after dried at $110^{\circ} \mathrm{C}$ during 6 hours, were calcinated in a muffle at $1000^{\circ} \mathrm{C}$ during a couple of hours, for loss on ignition (loi) determination. Fused bead was prepared from each calcinated sample, using lithium tetraborate flux, for X-ray fluorescence analyses. These analyses were performed in a Rigaku unit model RIX 3000 equipped with $\mathrm{Rh}$ tube, by the calibration curve method prepared with international reference materials. Major elements are reported in weight percent and trace elements, in parts per million (ppm, Table 1).

X-Ray Diffraction Analysis Analyses by XRD were 


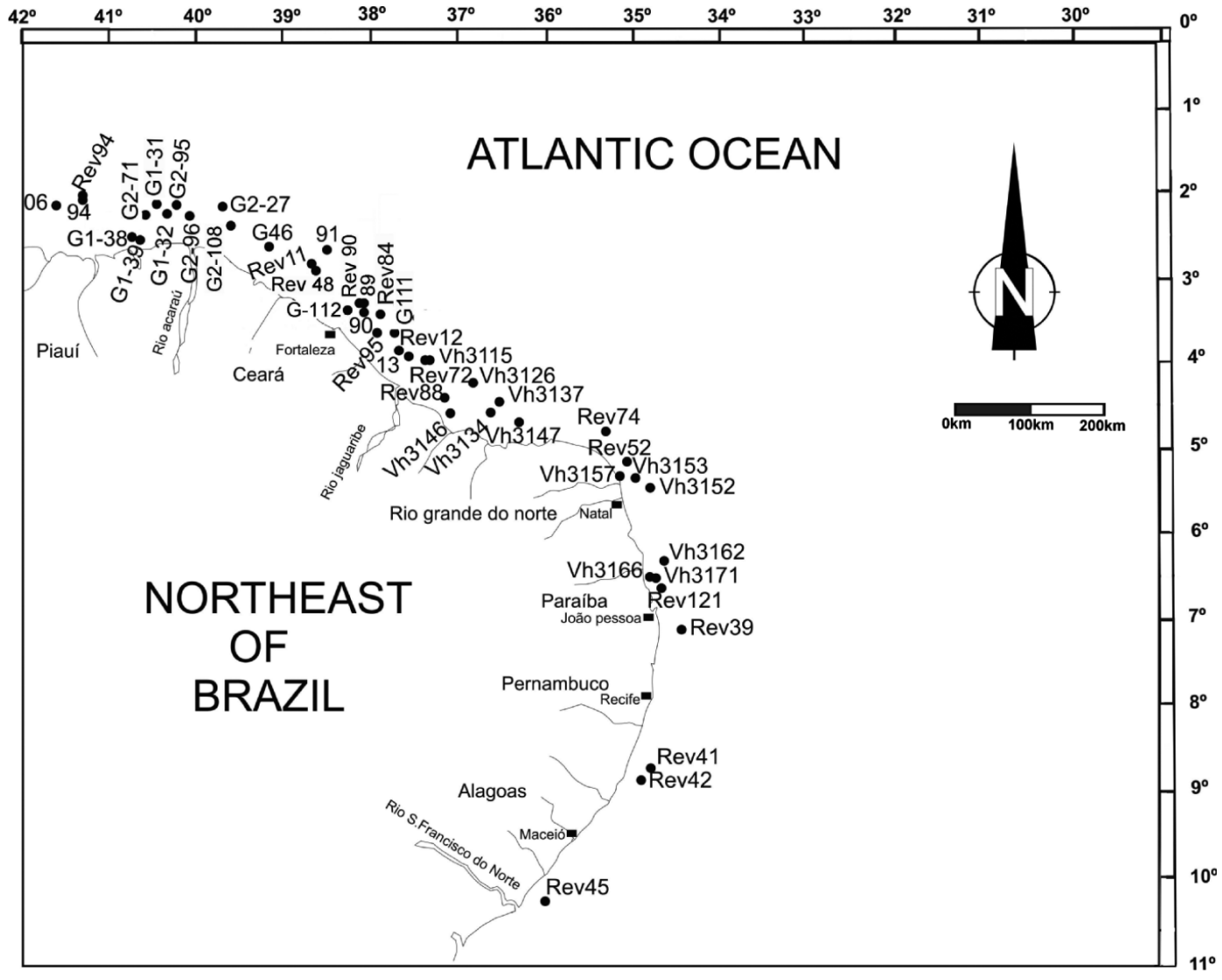

Figure 1 - Sample localities (adapted from Amaral, 1979).

performed by the powder method (Figs. 2a, b, c, d, e) using a Siemens D5000 unit, with the following standard conditions: scanning $\theta / \mathrm{min}$, from 5 to $50 \theta$. KCu $\alpha$ emission, and drift correction from the peak $\mathrm{I}=100$ of quartz $\alpha(3.34 \AA)$ to determining the magnesium quantity tied to the calcite structure, according to Goldsmith et al. (1961).

Statistical Analysis The statistical treatment of the data included a regression analysis by means of correlations among 14 variables by Spearman's correlation coefficients (r), (Table 2), at confidence level of $95 \%$, suitable for the type of population to be analyzed $(n=47)$, following suggestions in Siegel (1975).

RESULTS AND DISCUSSION The XRD analyses (Figs. 2a, b, c, d, e) have evidenced the predominance of the high Mg-calcite in proximal sediments of the continental shelf or in those characterized by fraction siliciclastic dominant (>60\% WS), even when they correspond to deep sediments $(>25 \mathrm{~m})$. Quartz and subordinate quantities of potassic feldspar are the main component of this siliciclastic fraction, with muscovite and clay minerals (kaolinite) only identifiable sporadically as accessory phases. Low Sr contents $(<2,200$ ppm. in general) and $\mathrm{Mg} / \mathrm{Ca}$ ratios (WS) $\geq 0.12$ (Fig. 3) characterize proximal facies, and place in evidence the reduced participation, or even absence of aragonite and of low Mg-calcite in total analyzed sediment (WS).

In more distal conditions of the continental shelf, deeper sediments $(>25 \mathrm{~m})$ where there is absolute predominance of the carbonatic fraction, high $\mathrm{Mg}$ calcite (sometimes more than one type) coexist with large amount of aragonite. The siliciclastic fraction, frequently accessory in this environment, sometimes is not identifiable by X-ray diffraction of whole sediment (WS). High Mg-calcite with Ca: $\mathrm{Mg}$ ratios of 85:15 to $80: 20$ predominate but at deeper isobath $(>35 \mathrm{~m})$, $\mathrm{Ca}: \mathrm{Mg}$ ratios of 70:30 can occur associated. High $\mathrm{Sr}$ contents $(>2,500 \mathrm{ppm})$ and $\mathrm{Mg} / \mathrm{Ca}(\mathrm{WS})$ ratios $<0.12$ (Fig. 2) characterize this paragenesis.

The predominance of high $\mathrm{Mg}$-calcites is ratified by strong contents of $\mathrm{MgO}(2.78$ a $6.89 \%)$ for WS with $\mathrm{CaCO}_{3 \text { total }}>95 \%$. Low Mg-calcites have not been identified. Samples with high Sr contents $(>3,000 \mathrm{ppm})$ had the presence of aragonite systematically confirmed in XRD analyses.

The results of statistical analyses attest, at a first instance, to the anticipated geochemical duality of shelf sedimentary systems, that is, the opposition between chemical species related to the supply of continental terrigenous sediments and those associated to carbonate precipitations that occur in situ. In this sense, it is aligned with terrigenous continental source the strong inter-correlations among $\mathrm{SiO}_{2}-\mathrm{Al}_{2} \mathrm{O}_{3}-\mathrm{K}_{2} \mathrm{O}-\mathrm{Rb}(\mathrm{Ta}-$ ble 2), generally with correlation coefficients $(\mathrm{r}) \geq 0.9$ to which somehow are also associated the set of intercorrelations $\mathrm{Fe}_{2} \mathrm{O}_{3}-\mathrm{Mn}-\mathrm{TiO}_{2}(\mathrm{r}=0.4$ a 0.8$)$. The set of inter-correlations between $\mathrm{SiO}_{2}-\mathrm{Al}_{2} \mathrm{O}_{3}-\mathrm{K}_{2} \mathrm{O}-\mathrm{Rb}$ marks the main siliciclastic constitution, composed by quartz 
Table 1 - Chemical analyses for bulk sediments collected at different depths (major elements in wt. \% and trace elements in ppm).

\begin{tabular}{|c|c|c|c|c|c|c|c|c|c|c|c|c|c|c|c|c|c|}
\hline & $\begin{array}{l}\text { Depth } \\
\text { (m) }\end{array}$ & Lat (S) & Long(W) & $\mathrm{SiO}_{2}$ & $\mathrm{Al}_{2} \mathrm{O}_{3}$ & $\mathrm{Fe}_{2} \mathrm{O}_{3} \mathrm{t}$ & $\mathrm{MgO}$ & $\mathrm{CaO}$ & $\mathrm{Na}_{2} \mathrm{O}$ & $\mathrm{K}_{2} \mathrm{O}$ & $\mathrm{TiO}_{2}$ & $\mathrm{P}_{2} \mathrm{O}_{5}$ & $\mathrm{PF}$ & $\mathrm{Mn}$ & $\mathrm{Sr}$ & $\mathrm{Rb}$ & $\begin{array}{c}\mathrm{Mg} / \\
\mathrm{Ca}\end{array}$ \\
\hline & 10 & & & 3.68 & & & & & & & 2.81 & & 0.98 & 549 & 820 & 15 & 0.22 \\
\hline Vh03 & 15 & 1 & $"$ & 05 & & & & .30 & & 04 & 0.19 & 06 & .77 & 46 & 629 & & 13 \\
\hline Rev88 & 18 & & '14'24" & . 00 & 00 & 03 & .97 & 8.39 & 0.41 & 0.01 & 0.03 & 07 & 6.92 & 16 & 052 & 5 & 0.10 \\
\hline Vh03147 & 20 & 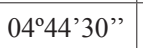 & '19'12" & 88.31 & 1.88 & 62 & 1.02 & 2.87 & 0.08 & 0.17 & 0.56 & .00 & 3.10 & 158 & 183 & 12 & 0.48 \\
\hline Rev74 & 20 & . & ${ }^{\circ} 19 ’ 30 "$ & 5.61 & & & 3.90 & 34.56 & 0.48 & 0.18 & 0.04 & . 05 & 35.14 & 16 & 3287 & 5 & 0.10 \\
\hline Vh03166 & 20 & ${ }^{\circ} 45^{\prime} 12$ " & '54'30" & 5.79 & 0.36 & 07 & 3.26 & 45.52 & 0.99 & 0.10 & 0.03 & .07 & 43.58 & 5 & 5301 & 5 & 0.06 \\
\hline G2 96 & 21 & '29’05" & $40^{\circ} 04^{\prime} 00^{\prime \prime}$ & 3.20 & 0.33 & 31 & 5.90 & 6.63 & 0.11 & 0.05 & 0.01 & 11 & 43.57 & 30 & 940 & 5 & 0.10 \\
\hline Vh0317 & 23 & 0 & ${ }^{\circ} 46^{\prime} 30^{\prime \prime}$ & 14.63 & 0.38 & 0 Q & 3.90 & 4111 & 0.48 & 0.04 & 0.02 & & 39.51 & 18 & 3588 & 5 & 0.08 \\
\hline G2 95 & 25 & & יפחיר ס־ם & 9.27 & 0.60 & & 5.50 & 72.00 & 0.30 & 0.23 & 0.01 & & 40.95 & 31 & 2626 & 5 & 0.11 \\
\hline G1 32 & 25 & 11700 & ${ }^{\circ} 27 ’ 30 "$ & 0.18 & & & 1.74 & 12.11 & 0.11 & 0.90 & 0.23 & & 13.09 & 90 & 1318 & 31 & 0.16 \\
\hline G2 71 & 25 & '31'05" & $40^{\circ} 35^{\prime} 00^{\prime \prime}$ & 8.53 & & 29 & 5.42 & 43.85 & 0.10 & 0.14 & 0.02 & 10 & 41.40 & 36 & 2611 & 5 & 0.10 \\
\hline G2 27 & 25 & 33 '05" & $39^{\circ} 47^{\prime} 03^{\prime \prime}$ & 12.43 & 1.39 & 033 & 4.31 & 40.56 & 0.32 & 0.35 & 0.08 & .09 & 40.52 & 40 & 3717 & 5 & 0.09 \\
\hline Rev12 & 25 & י" & $37^{\circ} 43^{\prime} 12^{\prime \prime}$ & 87.78 & & & & & & 0.22 & 0.28 & & 4.85 & 51 & 217 & 15 & 0.40 \\
\hline G1 12 & 25 & 5050 & '17'30" & 7.61 & & & 3.67 & 45.30 & 0.58 & 0.07 & 0.02 & & 42.51 & 17 & 4086 & 3 & 0.07 \\
\hline G2 108 & 2 & $35^{\prime} 09 "$ & ${ }^{\circ} 52 ’ 00 "$ & 23 & & & 5.54 & 48.48 & 0.20 & 0.03 & 0.01 & & 44.60 & 29 & 2689 & 5 & 0.09 \\
\hline Rev95 & 30 & 17'24'" & ${ }^{\circ} 00 ’ 00 ”$ & 12 & & & 2.78 & 50.62 & 0.69 & 0.03 & 0.01 & & 45.93 & 5 & 6482 & 0 & 0.04 \\
\hline Vh03134 & 30 & ${ }^{\circ} 48 ' 30$ ', & $36^{\circ} 37^{\prime} 42^{\prime \prime}$ & 0.67 & & 007 & 3.86 & 4017 & 0.76 & 0.04 & 0.02 & & 45.70 & 14 & 5200 & 0 & 0.06 \\
\hline 06 & & ${ }^{\circ} 18^{\prime} 00 "$ & & & & & & & & & & & & 11 & & ( & 0.09 \\
\hline 90 & 3 & $03^{\circ} 28^{\prime} 48^{\prime \prime}$ & $38^{\circ} 04^{\prime} 48^{\prime \prime}$ & & & & 52 & 0.88 & & 0.00 & 0.03 & & 45.41 & 18 & 4349 & 0 & 0.07 \\
\hline G1 31 & 35 & ${ }^{\circ} 15^{\prime} 00 "$ & $40^{\circ} 30^{\prime} 30^{\prime \prime}$ & 61.05 & & & 2.21 & 16.55 & 0.08 & 0.56 & 0.12 & .06 & 18.03 & 111 & 1550 & 20 & 0.13 \\
\hline 13 & 35 & $04^{\circ} 15^{\prime} 00^{\prime \prime}$ & $36^{\circ} 39^{\prime} 36^{\prime \prime}$ & 61.41 & 2.81 & 183 & 2.29 & 15.69 & 0.13 & 0.75 & 0.18 & 0.06 & 16.73 & 98 & 1226 & 25 & 0.15 \\
\hline Rev42 & & $09^{\circ} 06^{\prime} 00^{\prime \prime}$ & $34^{\circ} 33^{\prime} 36^{\prime \prime}$ & 66.86 & & & & & & & 0.15 & & 16.19 & 50 & 3326 & 25 & 0.09 \\
\hline 89 & & '28'48' & $38^{\circ} 04^{\prime} 48^{\prime \prime}$ & 0.39 & & & 2.78 & 50.10 & 0.66 & 0.05 & 0.01 & 0.08 & 45.94 & 16 & 6060 & 3 & 0.04 \\
\hline Rev90 & 35 & $03^{\circ} 28^{\prime} 48^{\prime \prime}$ & $38^{\circ} 04^{\prime} 48^{\prime \prime}$ & & & & & & & & 0.00 & & 45.45 & 12 & 4735 & 5 & 0.06 \\
\hline Rev121 & 35 & $06^{\circ} 48^{\prime} 00^{\prime \prime}$ & $34^{\circ} 39^{\prime} 36^{\prime \prime}$ & 16.83 & 1.83 & & 3.41 & 36.59 & & 0.28 & 0.11 & & 38.67 & 71 & 3063 & 10 & 0.08 \\
\hline Rev72 & 35 & $03^{\circ} 49^{\prime} 48^{\prime \prime}$ & $37^{\circ} 22^{\prime} 12^{\prime \prime}$ & 63.70 & & & & & & 0.76 & 0.08 & & & 53 & 2981 & 23 & 0.12 \\
\hline G 111 & 38 & $03^{\circ} 54^{\prime} 30^{\prime \prime}$ & $37^{\circ} 35^{\prime} 00^{\prime \prime}$ & 7.60 & 0.41 & 0.15 & 4.04 & 42.07 & 0.77 & 0.11 & 0.23 & 0.11 & 42.49 & 51 & 3174 & 3 & 0.08 \\
\hline
\end{tabular}

associated to potassic feldspar, apparently with absence (or in non-detectable amounts) of sodic plagioclase in XRD analysis. The set $\mathrm{Fe}_{2} \mathrm{O}_{3}-\mathrm{Mn}-\mathrm{TiO}_{2}(\mathrm{r}=0.7$ to 1.0$)$ point to the presence of a residual fraction of pedogenic origin, composed of $\mathrm{Fe}$ and $\mathrm{Mn}$ oxides, besides heavy minerals containing Ti (e.g. ilmenite and/or rutile). Although in non-systematic way, the highest contents of $\mathrm{Fe}_{2} \mathrm{O}_{3}, \mathrm{TiO}_{2}$ and $\mathrm{Mn}$, use to occur in more terrigenous facies, independently of the depth of sampling.

On the contrary, biogeochemical sedimentation, marked by integrated inter-correlations $\mathrm{CaO}-\mathrm{MgO}-\mathrm{P}_{2} \mathrm{O}_{5}$ $(\mathrm{r}=0.7$, systematically), is invariably opposed (negative r) to the terrigenous set as a whole. The diadochy of $\mathrm{Ca}^{++}$ for $\mathrm{Mg}^{++}$in the Mg-calcites composition and partition of $\mathrm{Ca}^{++}$in the composition of aragonite and Ca phosphates (probably apatite group) explain why the integrated correlations of the biochemical set are not so strong. An essentially benthonic bioclastic association, composed mainly by algae, mollusks, echinoids and corals, besides sporadic presence of scales, spines and fecal pellets. support the geochemical signatures of this set. The diversity of this biota and its corresponding mineralogical preservation allow a reasonable correlation between $\mathrm{CaO}-\mathrm{MgO}(\mathrm{r}=0.7)$, but weak between $\mathrm{Sr}-\mathrm{MgO}(\mathrm{r}=0.2)$ on account of the competition between $\mathrm{Sr}$ and $\mathrm{Mg}(\mathrm{r}=$ -0.8 for $\mathrm{Ca} / \mathrm{Mg}-\mathrm{Sr}$ ) in the carbonate composition.

The $\mathrm{Mg} / \mathrm{Ca}-\mathrm{SiO}_{2}$ correlation ( $\mathrm{r}=0.8$ ) evidence the geochemical competition between $\mathrm{Sr}$ and $\mathrm{Mg}$ in the integration to the crystallographic structure of the carbonates. By itself, it could indicate the influence of the depth in the Mg content of calcites, that is, the preferential formation of high Mg-calcites occur in facies proximal to the shelf, where the terrigenous fraction use to be stronger. However, in the studied sampling there are quartzous siliciclastic sediments $\left(\mathrm{SiO}_{2}>60 \%\right.$ and $\mathrm{Al}_{2} \mathrm{O}_{3}<3 \%$ ) from 10 to $55 \mathrm{~m}$, and the $\mathrm{Mg} / \mathrm{Ca}-\mathrm{SiO}_{2}$ correlation is more sensitive where the quartzous siliciclastic fraction is greater (Fig. 4), independently on depth of sampling. This way, it seems more evident that the mineralogical and chemical compositions of these sediments are directly related to the nature of the benthonic biota and this one with the type of substratum 
Table 1 - continued.

\begin{tabular}{|c|c|c|c|c|c|c|c|c|c|c|c|c|c|c|c|c|c|}
\hline Sample & $\begin{array}{l}\text { Depth } \\
\text { (m) }\end{array}$ & lat (S) & long (W) & $\mathrm{SiO}_{2}$ & $\begin{array}{c}\mathrm{Al}_{2} \mathrm{O} \\
3 \\
\end{array}$ & $\mathrm{Fe}_{2} \mathrm{O}_{3} \mathrm{t}$ & $\mathrm{MgO}$ & $\mathrm{CaO}$ & $\mathrm{Na}_{2} \mathrm{O}$ & $\mathrm{K}_{2} \mathrm{O}$ & $\mathrm{TiO}_{2}$ & $\mathrm{P}_{2} \mathrm{O}_{5}$ & PF & $\mathrm{Mn}$ & $\mathrm{Sr}$ & $\mathrm{Rb}$ & $\begin{array}{c}\mathrm{Mg} / \\
\mathrm{Ca}\end{array}$ \\
\hline Rev52 & 40 & $05^{\circ} 18^{\prime} 00^{\prime \prime}$ & $5^{\circ} 24 ’ 24^{\prime \prime}$ & 0.00 & 0.00 & 0.00 & 4.48 & 50.06 & 0.43 & 0.01 & 0.00 & 0.06 & 45.72 & 5 & 5133 & 0 & 0.07 \\
\hline G 46 & 40 & $02^{\circ} 57^{\prime} 30^{\prime \prime}$ & $39^{\circ} 16^{\prime} 30^{\prime \prime}$ & 0.60 & 0.16 & 0.16 & 5.68 & 49.08 & 0.31 & 0.00 & 0.00 & 0.11 & 44.86 & 14 & 2801 & 0 & 0.09 \\
\hline Rev75 & 40 & $03^{\circ} 16^{\prime} 30^{\prime \prime}$ & $35^{\circ} 06^{\prime} 00^{\prime \prime}$ & 0.15 & 0.01 & 0.04 & 5.47 & 46.21 & 0.73 & 0.30 & 0.00 & 0.07 & 47.27 & 15 & 3839 & 5 & 0.10 \\
\hline Rev41 & 43 & $09^{\circ} 04^{\prime} 48^{\prime \prime}$ & $35^{\circ} 01^{\prime} 12^{\prime \prime}$ & 0.33 & 0.03 & 0.02 & 3.11 & 50.42 & 0.47 & 0.01 & 0.00 & 0.07 & 44.87 & 16 & 4710 & 5 & 0.05 \\
\hline Rev39 & 55 & $07^{\circ} 28^{\prime} 48^{\prime \prime}$ & $34^{\circ} 46^{\prime} 48^{\prime \prime}$ & 70.31 & 2.75 & 0.15 & 1.72 & 12.20 & 0.50 & 0.73 & 0.04 & 0.02 & 13.83 & 29 & 2161 & 24 & 0.16 \\
\hline Rev48 & 60 & $03^{\circ} 20^{\prime} 24^{\prime \prime}$ & $38^{\circ} 40^{\prime} 12^{\prime \prime}$ & 0.03 & 0.00 & 0.03 & 3.19 & 51.19 & 0.63 & 0.00 & 0.00 & 0.08 & 45.46 & 18 & 3165 & 5 & 0.05 \\
\hline Rev94 & 60 & $02^{\circ} 18^{\prime} 00^{\prime \prime}$ & $41^{\circ} 27^{\prime} 36^{\prime \prime}$ & 0.15 & 0.00 & 0.07 & 4.98 & 48.19 & 0.90 & 0.12 & 0.03 & 0.12 & 47.74 & 16 & 3936 & 5 & 0.08 \\
\hline VH3115 & 60 & $04^{\circ} 15^{\prime} 00^{\prime \prime}$ & $37^{\circ} 24^{\prime} 30^{\prime \prime}$ & 4.60 & 0.35 & 0.05 & 4.78 & 46.21 & 0.57 & 0.14 & 0.01 & 0.08 & 43.65 & 9 & 3200 & 5 & 0.08 \\
\hline 94 & 60 & $02^{\circ} 18^{\prime} 00^{\prime \prime}$ & $41^{\circ} 27^{\prime} 36^{\prime \prime}$ & 0.58 & 0.06 & 0.05 & 4.45 & 46.28 & 0.65 & 0.12 & 0.02 & 0.10 & 47.43 & 30 & 4314 & 5 & 0.08 \\
\hline VH3137 & 60 & $04^{\circ} 40^{\prime} 00^{\prime \prime}$ & $36^{\circ} 34^{\prime} 42^{\prime \prime}$ & 2.50 & 0.45 & 0.14 & 3.81 & 48.13 & 0.82 & 0.09 & 0.03 & 0.10 & 44.80 & 20 & 4051 & 5 & 0.06 \\
\hline Rev45 & 60 & $10^{\circ} 36^{\prime} 00^{\prime \prime}$ & $36^{\circ} 24^{\prime} 00^{\prime \prime}$ & 6.59 & 0.46 & 0.32 & 5.18 & 44.00 & 0.48 & 0.09 & 0.04 & 0.09 & 43.44 & 43 & 2882 & 5 & 0.09 \\
\hline VH3153 & 60 & $05^{\circ} 46^{\prime} 00^{\prime \prime}$ & $35^{\circ} 00^{\prime} 30^{\prime \prime}$ & 7.83 & 1.07 & 1.17 & 3.85 & 43.57 & 0.66 & 0.19 & 0.06 & 0.17 & 41.52 & 76 & 3063 & 5 & 0.07 \\
\hline Rev84 & 80 & $03^{\circ} 39^{\prime} 36^{\prime \prime}$ & $38^{\circ} 00^{\prime} 00^{\prime \prime}$ & 0.37 & 0.02 & 0.02 & 5.72 & 48.26 & 0.44 & 0.00 & 0.00 & 0.08 & 45.79 & 10 & 3120 & 5 & 0.10 \\
\hline Rev11 & 80 & $03^{\circ} 01^{\prime} 48^{\prime \prime}$ & $38^{\circ} 46^{\prime} 12^{\prime \prime}$ & 0.05 & 0.00 & 0.03 & 4.78 & 49.20 & 0.41 & 0.00 & 0.02 & 0.10 & 46.78 & 18 & 3890 & 5 & 0.08 \\
\hline VH3126 & 80 & $04^{\circ} 34^{\prime} 42^{\prime \prime}$ & $36^{\circ} 53^{\prime} 24^{\prime \prime}$ & 3.46 & 0.62 & 0.15 & 3.11 & 46.20 & 0.70 & 0.12 & 0.03 & 0.08 & 43.85 & 22 & 3888 & 5 & 0.06 \\
\hline VH3162 & 80 & $06^{\circ} 39^{\prime} 42^{\prime \prime}$ & $34^{\circ} 43^{\prime} 18^{\prime \prime}$ & 3.90 & 1.76 & 0.79 & 4.33 & 44.26 & 0.79 & 0.13 & 0.08 & 0.10 & 44.03 & 73 & 3816 & 5 & 0.08 \\
\hline
\end{tabular}

Table 2 - Correlation matrix for major elements (wt.\% oxides) and trace elements (ppm).

\begin{tabular}{|c|c|c|c|c|c|c|c|c|c|c|c|c|c|c|}
\hline $\mathrm{SiO}_{2}$ & 1.0 & $\mathrm{Al}_{2} \mathrm{O}_{3}$ & & & & & & & & & & & & \\
\hline $\mathrm{Al}_{2} \mathrm{O}_{3}$ & 0.9 & 1.0 & $\mathrm{Fe}_{2} \mathrm{O}_{3} \mathrm{t}$ & & & & & & & & & & & \\
\hline $\mathrm{Fe}_{2} \mathrm{O}_{3} \mathrm{t}$ & 0.5 & 0.7 & 1.0 & $\mathrm{MgO}$ & & & & & & & & & & \\
\hline $\mathrm{MgO}$ & -0.8 & -0.7 & -0.3 & 1.0 & $\mathrm{CaO}$ & & & & & & & & & \\
\hline $\mathrm{CaO}$ & -1.0 & -0.9 & -0.5 & 0.7 & 1.0 & $\mathrm{Na}_{2} \mathrm{O}$ & & & & & & & & \\
\hline $\mathrm{Na}_{2} \mathrm{O}$ & -0.3 & -0.2 & -0.1 & -0.1 & 0.3 & 1.0 & $\mathrm{~K}_{2} \mathrm{O}$ & & & & & & & \\
\hline $\mathrm{K}_{2} \mathrm{O}$ & 0.8 & 0.9 & 0.4 & -0.6 & -0.8 & -0.1 & 1.0 & $\mathrm{TiO}_{2}$ & & & & & & \\
\hline $\mathrm{TiO}_{2}$ & 0.4 & 0.5 & 0.7 & -0.3 & -0.5 & -0.2 & 0.1 & 1.0 & $\mathrm{P}_{2} \mathrm{O}_{5}$ & & & & & \\
\hline $\mathrm{P}_{2} \mathrm{O}_{5}$ & -0.8 & -0.5 & 0.0 & 0.7 & 0.7 & 0.2 & -0.5 & -0.3 & 1.0 & $\mathrm{PF}$ & & & & \\
\hline $\mathrm{PF}$ & -1.0 & -0.9 & -0.5 & 0.8 & 1.0 & 0.4 & -0.7 & -0.5 & 0.8 & 1.0 & $\mathrm{Mn}$ & & & \\
\hline $\mathrm{Mn}$ & 0.5 & 0.6 & 0.8 & -0.4 & -0.6 & -0.3 & 0.2 & 1.0 & -0.3 & -0.5 & 1.0 & $\mathrm{Sr}$ & & \\
\hline $\mathrm{Sr}$ & -0.7 & -0.7 & -0.5 & 0.2 & 0.7 & 0.6 & -0.5 & -0.4 & 0.3 & 0.7 & -0.5 & 1.0 & $\mathrm{Rb}$ & \\
\hline $\mathrm{Rb}$ & 0.9 & 0.9 & 0.4 & -0.7 & -0.9 & -0.2 & 0.9 & 0.3 & -0.6 & -0.8 & 0.4 & -0.6 & 1.0 & $\mathrm{Mg} / \mathrm{Ca}$ \\
\hline $\mathrm{Mg} / \mathrm{Ca}$ & 0.8 & 0.5 & 0.3 & -0.4 & -0.8 & -0.5 & 0.3 & 0.4 & -0.6 & -0.8 & 0.4 & -0.8 & 0.4 & 1.0 \\
\hline
\end{tabular}

they are tied to.

It is possible that such distal siliciclastic sediments observed in these deep isobaths $(>25 \mathrm{~m})$ correspond to ancient reworked coastal zones, not covered by more recent sediments, marking periods of stabilizations of coastline during the rising of sea level from the peak of the latest glacial period.

Original records should be certainly covered by subsequent process of sedimentation. In this sense, regarding the gentle gradient of the shelf and the order of magnitude of the sedimentation rates of the shallow carbonatic platforms (0.5-1.5 m $1000 \mathrm{yr}^{-1}$, Tucker and
Wright 1990) in few thousand years these deposit could be sufficiently covered by more recent sediments precluding their sampling by oceanic dredgers. Alternatively, these deeper quartzous terrigenous facies could correspond to active axes of currently submerse paleochannels still receiving continental detritic materials by means of plumes of the present-day drainage systems. In any of these alternatives, the siliciclastic nature of these substrata seem as important as the hydrodynamic conditions or temperature of the water to the mineralogy and geochemistry of the associated carbonates. Therefore, among the possibilities pointed out by Morse and 

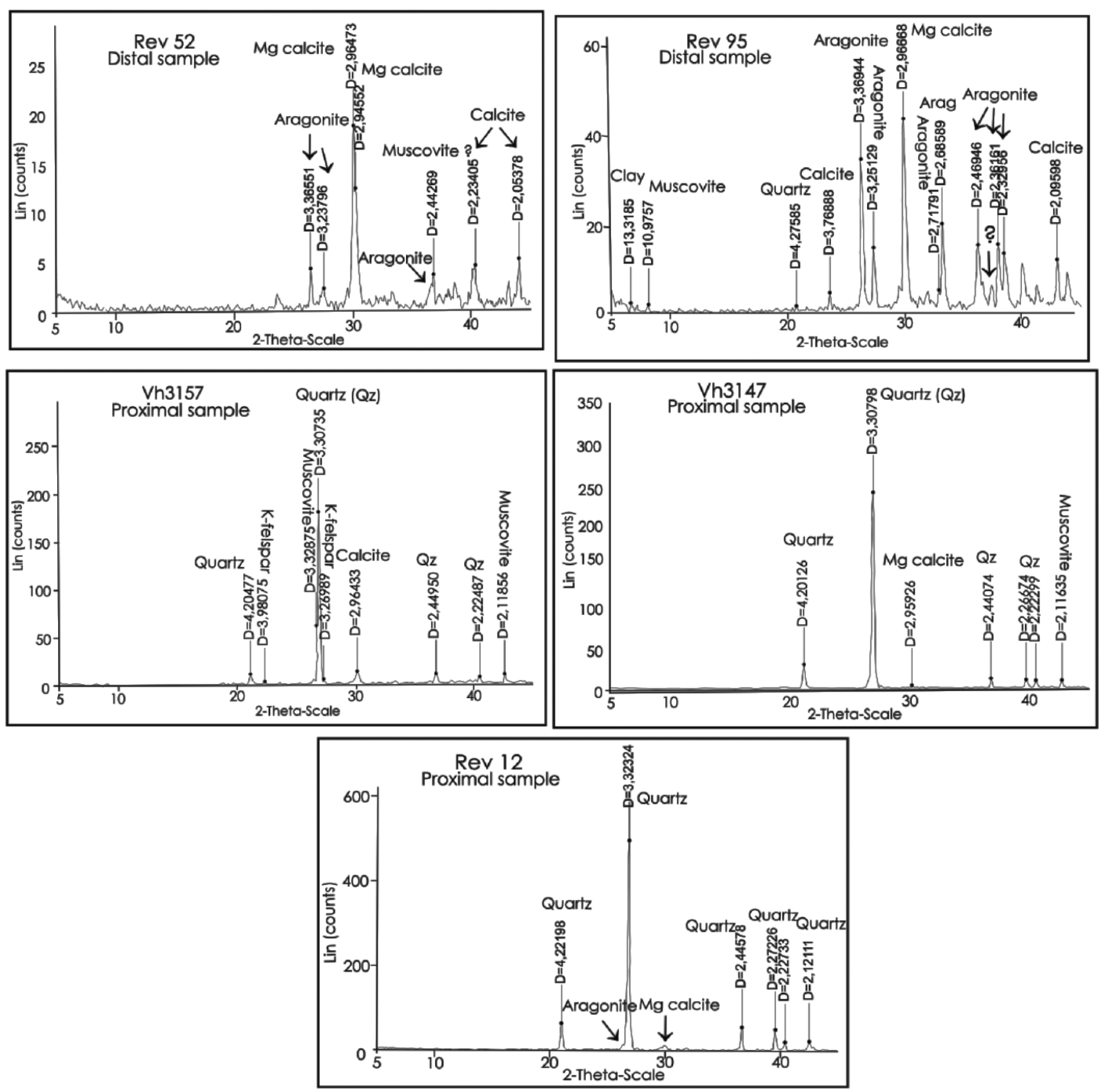

Figure 2 - Diffractograms of samples collected at different depths. (a) sample rev52, collected from $40 \mathrm{~m}$ depth; (b) sample rev95, from $30 \mathrm{~m}$ depth; (c) sample vh3157, from $10 \mathrm{~m}$ deep; (d) sample vh3147, from $20 \mathrm{~m}$ deep; (e) sample rev 12, from $25 m$ deep.

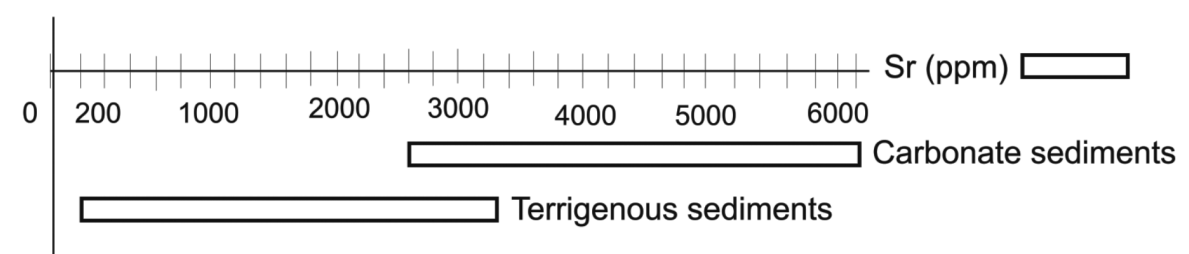

Carbonate sediments

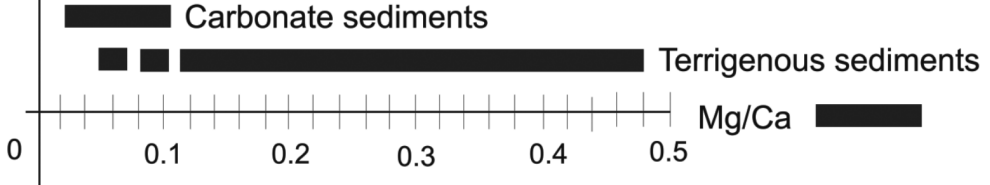

Figure 3 - $\mathrm{Sr}(\mathrm{ppm})$ and $\mathrm{Mg} / \mathrm{Ca}$ ratios, respectively for terrigenous and carbonatic sediments, in the continental shelf in the oriental Northeastern Brazil. 


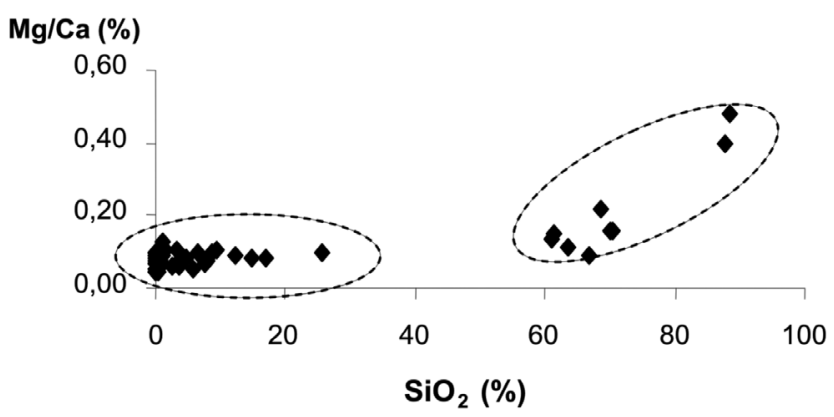

Figure 4 - Scattering diagram ( $\mathrm{SiO}_{2}$ versus $\mathrm{Mg} / \mathrm{Ca}$ ) for samples collected among 10 and $80 \mathrm{~m}$ depth. The correlation $\mathrm{Mg} / \mathrm{Ca}$ is high in samples with more quartz, independent of depth.

Mackenzie (1990) it is suggested to discard the temperature effect, since the expected difference between 10 and 55 meters of depth would be of the order of a few degrees centigrades, retaining the conception of "biota differences".

In the case of $\mathrm{Na}_{2} \mathrm{O}$, there is an undefined behavior with weak negative correlations with all of the terrigenous set, in concordance with the absence of sodic plagioclase. Its co-variance with $\mathrm{CaO}(\mathrm{r}=0.3)$ and mainly that with $\mathrm{Sr}(\mathrm{r}=0.6)$ suggest that, as already pointed out by Okamura and Kitano (1986) and Tucker and Wright (1990) that sodium can be tied to the crystallographic structure of carbonates.

CONCLUSIONS The analytical results revealed two types of bottom sediments:

(a) Terrigenous sediments: with predominance of quartz and residual quantities of potassic feldspars and heavy minerals (probably: ilmenite, goethite and Mn oxides). In these sediments the terrigenous fraction is stoichiometrically, superior to $65 \% \mathrm{WS}$, and the carbonatic fraction $(<35 \%)$ uses to be represented predominantly by high $\mathrm{Mg}$-calcites being in general, observed $\mathrm{Mg} / \mathrm{Ca}$ ratios $\geq 0.12$ and $\mathrm{Sr}<2,200 \mathrm{ppm}$;

b) Carbonatic sediments: with predominance shared by high Mg-calcite and aragonite and even dominance of aragonite, accompanied of accessory quantities of terrigenous fraction (generally $<5 \%$ ). In these sediments, it is usually observed $\mathrm{Mg} / \mathrm{Ca}$ ratios $<0.12$ and $\mathrm{Sr}>2,600 \mathrm{pm}$.

Even with low amounts of $\mathrm{Al}_{2} \mathrm{O}_{3}(<3 \%$ in $95.5 \%$ of the cases; average of $0.8 \%$ ) strong integrated correlations among $\mathrm{SiO}_{2}-\mathrm{Al}_{2} \mathrm{O}_{3}-\mathrm{K}_{2} \mathrm{O}-\mathrm{Rb}$ have shown to be preserved confirming the quartz and potassic feldspar paragenesis in accordance with the felsic nature of the crystalline basement on which the costal drainage system has been established.

The quantity of $\mathrm{Mg}$ inserted in crystallographic structures of calcite in the studied shelf is statistically associated to a greater participation of the quartzousterrigenous fraction in the bulk sediments of the substratum that govern the development of the benthonic biota kept in high Mg-calcite instead of the biota kept in aragonite. This tendency has proven to be independent on the depth of sampling from 10 to $55 \mathrm{~m}$.

Acknowledgements We thank the Department of Physics of the Federal University of Pernambuco (UFPE) for XRD analyses. Wanessa S. Marques wants to express her gratitude to the Brazilian CAPES Agency for a doctoral scholarship granted to her during her stay at the UFPE. This is the NEG-LABISE contribution n. 246.

\section{References}

Brownlow A.H. 1996. Geochemistry. 2nd Edition, USA, Prentice-Hall, 580p.

Bilal U.H. \& Boersma A. (eds.) 1998. Introduction to marine micropaleontology. Elsevier, Netherlands, 376p.

Coutinho P.N. 1992. Sedimentos carbonáticos da plataforma continental brasileira. Rev. Geologia UFC, 6: 65-73.

Dana H. 1959. Manual de Mineralogia. São Paulo, Livros técnicos e científicos S.A, Universidade de São Paulo, $640 \mathrm{p}$.

Freire G.S.S. 1985. Geologia marinha da plataforma continental do Ceará. Dissertação de mestrado em Geociências, Universidade Federal de Pernambuco, 132p.

Goldsmith J.R., Donald L.G., Heard H.C. 1961. Lattice constants of the calcium-magnesium carbonates. Amer. Mineralogist., 46:453-457.

Morse W.J. \& Mackenzie F.T. 1990. Geochemistry of sedimentary carbonates. Amsterdam, Elsevier, 679p.

Montalverne A.A.F. 1982. Estudo dos calcários na plataforma continental de Pernambuco. Dissertação de mestrado em Geociências, Universidade Federal de Pernambuco, $197 \mathrm{p}$.
Meireles A.J.A. \& Silva V.E. 2002. Abordagem geomorfológica para a realização de estudos integrados para o planejamento e gestão em ambientes flúvio-marinhos. Scripa Nova-Rev Electr Geografía y Ciências Sociales, VI:118

Okamura M. \& Kitano Y. 1986. Coprecipitation of alkali metal íons with calcium carbonate. Geochim. Cosmochim. Acta, 50:49-58.

Siegel S. 1975. Estatística não paramétrica para Ciências do Comportamento. São Paulo, MacGraw-Hill do Brasil, 500p.

Summerhayes C.P., Coutinho A.P.N., França M.C., Ellis J.P. 1975. Uppon continental margin sedimentation of Brazil. Contrib Sedimentology, 4:44-78.

Tucker M. \& Wright V.P. 1990. Carbonate Sedimentology. Oxford, Blackwell Sci. Publ, 421p.

Manuscrito AE 086-2006 Submetido em 22 de maio de 2007 Aceito em 01 de dezembro de 2007 